Article

\title{
Xanthine Oxidase Inhibitory Activity and Thermostability of Cinnamaldehyde-Chemotype Leaf Oil of Cinnamomum osmophloeum Microencapsulated with $\beta$-Cyclodextrin
}

\author{
Chi-Ya Huang ${ }^{1}$, Ting-Feng Yeh ${ }^{1}$, Fu-Lan Hsu ${ }^{2}$, Chun-Ya Lin ${ }^{1}$, Shang-Tzen Chang ${ }^{1}$ \\ and Hui-Ting Chang ${ }^{1, *}$ \\ 1 School of Forestry and Resource Conservation, National Taiwan University, Taipei 106, Taiwan; \\ r99625047@ntu.edu.tw (C.-Y.H.); stfyeh@ntu.edu.tw (T.-F.Y.); aisiteru555@gmail.com (C.-Y.L.); \\ peter@ntu.edu.tw (S.-T.C.) \\ 2 Division of Forest Chemistry, Taiwan Forestry Research Institute, Council of Agriculture, Executive Yuan, \\ Taipei 100, Taiwan; fulan40@gmail.com \\ * Correspondence: chtchang@ntu.edu.tw; Tel.: +886-2-3366-5880; Fax: +886-2-2365-4520
}

Academic Editor: Francesca Giampieri

Received: 6 April 2018; Accepted: 4 May 2018; Published: 7 May 2018

\begin{abstract}
The xanthine oxidase inhibitory activity and thermostability of Cinnamomum osmophloeum leaf oil microencapsulated with $\beta$-cyclodextrin were evaluated in this study. The yield of leaf oil microcapsules was $86.3 \%$ using the optimal reaction conditions at the leaf oil to $\beta$-cyclodextrin ratio of 15:85 and ethanol to water ratio ranging from 1:3 to 1:5. Based on the FTIR analysis, the characteristic absorption bands of major constituent, trans-cinnamaldehyde, were confirmed in the spectra of leaf oil microcapsules. According to the dry-heat aging test, $\beta$-cyclodextrin was thermostable under the high temperature conditions, and it was beneficial to reduce the emission of $C$. osmophloeum leaf oil. Leaf oil microcapsules exhibited high xanthine oxidase inhibitory activity, with an $\mathrm{IC}_{50}$ value of $83.3 \mu \mathrm{g} / \mathrm{mL}$. It is concluded that the lifetime of $C$. osmophloeum leaf oil can be effectively improved by microencapsulation, and leaf oil microcapsules possess superior xanthine oxidase inhibitory activity.
\end{abstract}

Keywords: trans-cinnamaldehyde; Cinnamomum osmophloeum; $\beta$-cyclodextrin; microencapsulation; xanthine oxidase inhibitory activity

\section{Introduction}

Cinnamon plants (Cinnamomum spp., Lauraceae) are woody species native to South and Southeast Asia, commonly used as food flavors and folk medicinal plants. Cinnamomum osmophloeum Kanehira has long been used as a medicinal plant. Natural products obtained from cinnamon plants display versatile bioactivities, including antibacterial, antifungal, antioxidant, and anxiolytic effects, etc. [1-5].

Plant essential oils and extracts with antimicrobial, anti-inflammatory, analgesic, anxiolytic, and other properties are widely used for perfumes, food additives, pharmaceuticals, and so on $[6,7]$. Essential oils are rich in highly volatile simple aromatics, monoterpenoids and sesquiterpenoids. The highly volatile character of essential oils results in the quick release to the environment of their components. Thermal-induced oxidation and degradation of the essential oil also occur easily. These restrictions limit the lifetime and utilization of essential oil products. Microencapsulation of highly volatile leaf oils with proper shell materials can help improve their durability.

C. osmophloeum leaf oils from different sources are classified into several chemotypes, mainly including cinnamyl acetate-type, linalool-type, cinnamaldehyde-type, and the others types. 
Among these chemotypes of C. osmophloeum leaf oils, the cinnamaldehyde type leaf oil showed xanthine oxidase inhibitory activity and anti-hyperuricemia effects [1]. Xanthine oxidase is the key enzyme that catalyzes the oxidation of hypoxanthine/xanthine to produce uric acid; excess accumulation of uric acid leads to diseases such as gout and hyperuricemia. Cinnamaldehyde is a common antiallergic, anti-inflammatory, and antipyretic drug in traditional medicine. Cinnamaldehyde is approved as a Generally Recognized as Safe (GRAS) natural food additive by the United States Food and Drug Administration.

Common microcapsule shell materials include gum arabic, gelatin, cyclodextrins, sodium caseinate, cellulose derivatives, sodium alginate, chitosans, etc. [8-10]. Cyclodextrins, amphiphilic hollow polysaccharides, have been used as effective carriers for food and drug delivery in the food, pharmaceutical and biomedical fields [11-14]. $\beta$-Cyclodextrin is one of the most common microcapsule shell materials with advantages such as photostability and thermostability [6,15-17]. Many plant essential oils contain $p$-cymene, a monoterpenoid with highly volatile properties, possessing analgesic and anti-inflammation activities. Because the half-lifetime of $p$-cymene is short; it brings the problem for the storage and utilization. Quintans et al. [18] microencapsulated $p$-cymene by $\beta$-cyclodextrin to improve its stability and pharmacological activity. trans-Cinnamaldehyde, a major compound in cinnamon leaf oil, is classified as a phenylpropanoid and cinammic acid derivative in the classification of natural products. Microencapsulated bioactive plant essential oils with more functional properties can be applied in the food and pharmaceutical industries. Jiang et al. [19] investigated the combination of $\beta$-cyclodextrin and its derivatives with $C$. loureirii bark oil, which was rich in trans-cinnamaldehyde (69.6\%). Among the three materials studied, which included $\beta$-cyclodextrin ( $\beta-C D), 2,6$-di-O-methyl- $\beta-C D(D M-\beta-C D)$, and 2-O-(2-hydroxypropyl)- $\beta$-CD (HP- $\beta-C D)$, the inclusion ability of $\beta$-cyclodextrin was better than that of the other two derivatives, so in this study, $\beta$-cyclodextrin was selected as the microcapsule shell material.

The purposes of this study were to microencapsulate cinnamaldehyde-type leaf oil of C. osmophloeum with $\beta$-cyclodextrin and examine the properties of the resulting leaf oil microcapsules. It was expected that the preservation of $C$. osmophloeum leaf oil would improve. Xanthine oxidase inhibitory activity and thermostability of $C$. osmophloeum leaf oil microcapsules were investigated to confirm the properties of the leaf oil microcapsules.

\section{Results and Discussion}

\subsection{Composition of Cinnamomum Osmophloeum Leaf Oil}

A schematic illustration of the hydrodistillation of Cinnamomum osmophloeum leaf oil and microencapsulation of the leaf oil with $\beta$-cyclodextrin is shown in Figure 1.

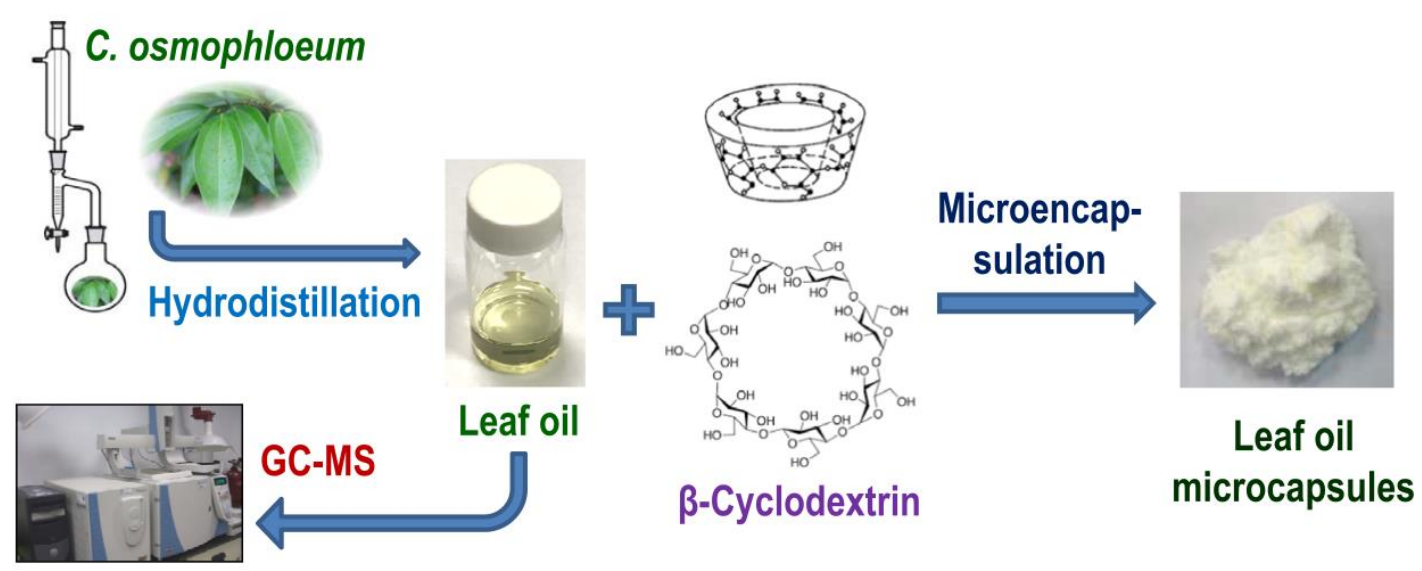

Figure 1. Schematic illustration of microencapsulation of C. osmophloeum leaf oil with $\beta$-cyclodextrin. 
The composition of the leaf oil was analyzed using GC-MS. Figure 2 shows a gas chromatogram of the leaf oil. The main constituents of the examined C. osmophloeum leaf oil were trans-cinnamaldehyde $(84.13 \%)$, benzaldehyde (7.16\%), 3-phenylpropionaldehyde (3.62\%), $\alpha$-pinene (1.09\%), L-bornyl acetate $(0.92 \%)$, and camphene $(0.79 \%)$ (Table 1$)$. The content of trans-cinnamaldehyde was much higher than that of the other constituents, so the leaf oil was classified as belonging to the cinnamaldehyde chemotype of C. osmophloeum. Based on the variation of major constituents, C. osmophloeum leaf oils can be classified into several chemotypes with individual bioactivity. Eugenol is a common compound found in the Cinnamomum plants. In this study, eugenol was a minor constituent $(0.03 \%)$ of the selected leaf oil. The main constituents of the C. osmophloeum leaf oil were volatile aromatics and terpenoids.

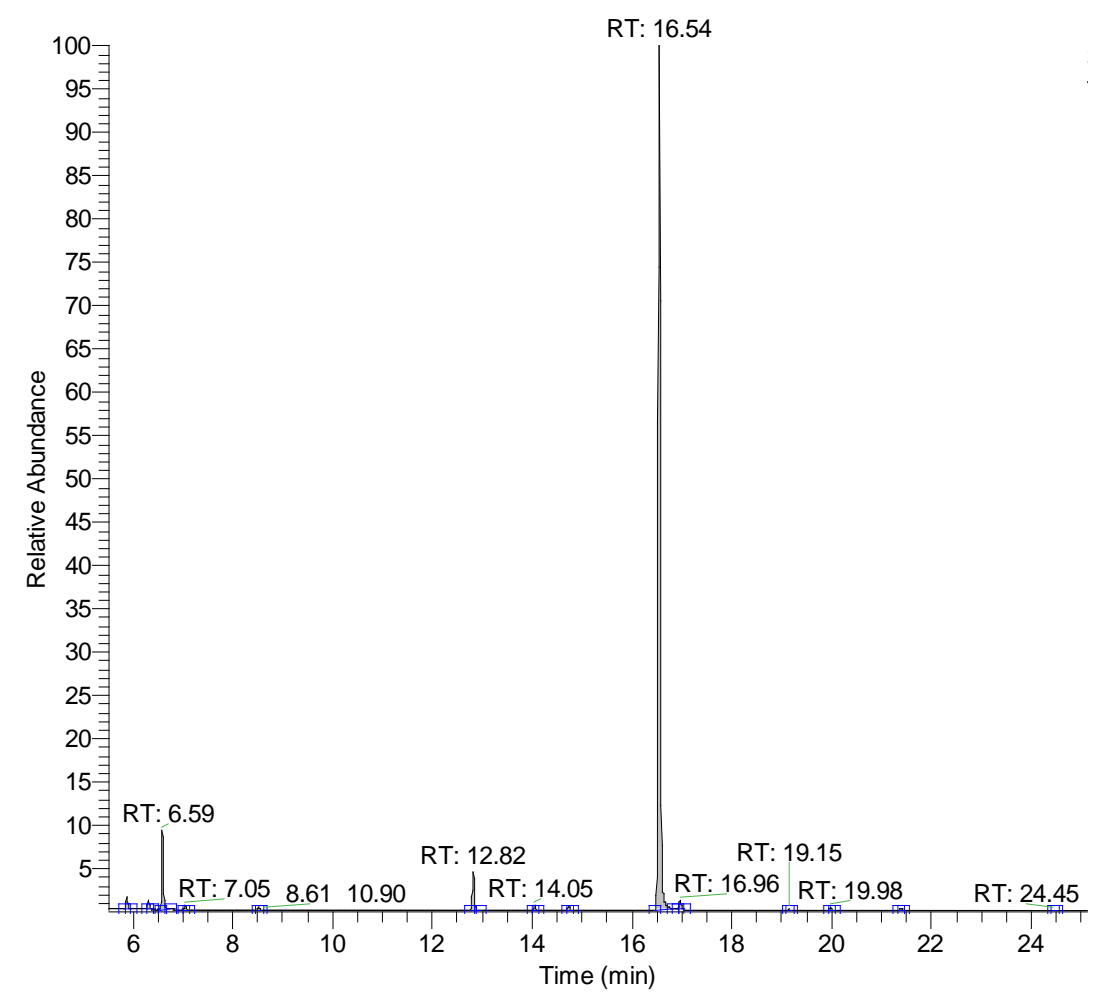

Figure 2. Gas chromatogram of cinnamaldehyde-type C. osmophloeum leaf oil.

Table 1. Composition of Cinnamomum osmophloeum leaf oil.

\begin{tabular}{cccccc}
\hline $\mathbf{R t}(\mathbf{m i n})$ & KI & Constituent & Formula & Content (\%) & Identification Method \\
\hline 5.86 & 938 & $\alpha$-Pinene & $\mathrm{C}_{10} \mathrm{H}_{16}$ & 1.09 & MS, KI \\
6.30 & 955 & Camphene & $\mathrm{C}_{10} \mathrm{H}_{16}$ & 0.79 & MS, KI \\
6.59 & 965 & Benzaldehyde & $\mathrm{C}_{7} \mathrm{H}_{6} \mathrm{O}$ & 7.16 & MS, KI \\
7.05 & 982 & $\beta$-Pinene & $\mathrm{C}_{10} \mathrm{H}_{16}$ & 0.36 & MS, KI \\
8.61 & 1033 & Limonene & $\mathrm{C}_{10} \mathrm{H}_{16}$ & 0.21 & MS, KI \\
12.82 & 1164 & 3-Phenylpropionaldehyde & $\mathrm{C}_{9} \mathrm{H}_{10} \mathrm{O}$ & 3.62 & MS, KI \\
14.05 & 1198 & Methyl chavicol & $\mathrm{C}_{10} \mathrm{H}_{12} \mathrm{O}$ & 0.55 & MS, KI \\
14.72 & 1219 & cis-Cinnamaldehyde & $\mathrm{C}_{9} \mathrm{H}_{8} \mathrm{O}$ & 0.50 & MS, KI \\
16.54 & 1273 & trans-Cinnamaldehyde & $\mathrm{C}_{9} \mathrm{H}_{8} \mathrm{O}$ & 84.13 & MS, KI \\
16.96 & 1285 & L-Bornyl acetate & $\mathrm{C}_{12} \mathrm{H}_{20} \mathrm{O}_{2}$ & 0.92 & MS, KI \\
19.15 & 1351 & Eugenol & $\mathrm{C}_{10} \mathrm{H}_{12} \mathrm{O}_{2}$ & 0.03 & MS, KI \\
19.98 & 1376 & $\alpha$-Copaene & $\mathrm{C}_{15} \mathrm{H}_{24}$ & 0.34 & MS, KI \\
21.40 & 1420 & $\beta-$-Caryophyllene & $\mathrm{C}_{15} \mathrm{H}_{24}$ & 0.29 & MS, KI \\
24.45 & 1517 & $\delta$-Cadinene & $\mathrm{C}_{15} \mathrm{H}_{24}$ & 0.02 & MS, KI \\
\hline$*$ RT: Retention time $(\mathrm{min}) * *$ KI: Kovats index relative to $n$-alkanes $(C 9-C 24)$ on a DB-5MS column
\end{tabular}

${ }^{*}$ RT: Retention time $(\mathrm{min}) ;{ }^{* *} \mathrm{KI}$ : Kovats index relative to $n$-alkanes (C9-C24) on a DB-5MS column. 


\subsection{Optimal Microencapsulation of C. Osmophloeum Leaf Oil with $\beta$-Cyclodextrin}

The influence of the trans-cinnamaldehyde to $\beta$-cyclodextrin ratio on the microcapsule yield is shown in Table 2. $\beta$-Cyclodextrin completely dissolved in the solution (ethanol/water, $1: 5 \mathrm{v} / \mathrm{v}$ ) at $50{ }^{\circ} \mathrm{C}$ for $5 \mathrm{~min}$, then the solution was cooled without adding the core material, trans-cinnamaldehyde, and no crystals occurred/precipitated even at $4{ }^{\circ} \mathrm{C}$. The highest yield of microcapsules $(83.7 \%)$ was achieved at the trans-cinnamaldehyde to $\beta$-cyclodextrin ratio of $15: 85(w / w)$, which was close to a 1:1 molar ratio. The other weight ratios significantly decreased the microcapsule yield ranged from 68.8 to $72.8 \%$.

Table 2. Yields of trans-cinnamaldehyde and leaf oil microencapsulated with $\beta$-cyclodextrin.

\begin{tabular}{|c|c|c|c|}
\hline Specimen & Specimen: $\beta-\mathrm{CD}(w / w)$ & $\mathrm{EtOH}: \mathrm{H}_{2} \mathrm{O}(v / v)$ & Yield (\%) \\
\hline \multirow{5}{*}{ trans-Cinnamaldehyde } & $0: 100$ & 1:5 & $0.0 \pm 0.0^{c *}$ \\
\hline & $10: 90$ & $1: 5$ & $68.8 \pm 1.1^{b}$ \\
\hline & $15: 85$ & $1: 5$ & $83.7 \pm 0.7^{\mathrm{a}}$ \\
\hline & $20: 80$ & $1: 5$ & $72.8 \pm 1.2^{b}$ \\
\hline & $25: 75$ & $1: 5$ & $70.8 \pm 1.5^{b}$ \\
\hline \multirow{5}{*}{ trans-Cinnamaldehyde } & $15: 85$ & $1: 7$ & $75.5 \pm 1.2^{\mathrm{B}}$ \\
\hline & $15: 85$ & $1: 5$ & $83.7 \pm 0.7^{\mathrm{A}}$ \\
\hline & $15: 85$ & $1: 4$ & $85.0 \pm 0.9^{\mathrm{A}}$ \\
\hline & 15:85 & $1: 3$ & $87.3 \pm 1.1^{\mathrm{A}}$ \\
\hline & $15: 85$ & $1: 2$ & $65.0 \pm 1.8^{C}$ \\
\hline Leaf oil & $15: 85$ & $1: 3$ & $86.3 \pm 2.0$ \\
\hline
\end{tabular}

* Different letters (a-c and A-C) in the table refer to statistically significant differences at the level of $p<0.05$ according to Scheffe's test.

Microencapsulation of C. zeylanicum leaf oil and garlic (Allium sativum) oil in $\beta$-cyclodextrin was reported by Ayala-Zavala et al. [20]. The main components of C. zeylanicum leaf oil and garlic oil were eugenol $(78 \%)$ and allyl disulfide $(21 \%)$, respectively. The highest yields of $C$. zeylanicum leaf oil and garlic oil microencapsulation with $\beta$-cyclodextrin were obtained at the weight ratios of 16:84 and 12:88.

Another important factor in the microencapsulation was the ratio of ethanol to water in the reaction solution. For the 1:7 and 1:2 ratios of ethanol to water $(v / v)$, yields of microcapsules were lower than that of the other ratios and below $80 \%$. The 1:3 ratio of ethanol to water showed the maximum microcapsule yield $(87.3 \%)$, but the difference was not statistically significant $(p<0.05)$ for the 1:4 and 1:5 ratios. With the optimal conditions for microencapsulation, the yield of cinnamaldehyde type leaf oil microcapsules was $86.3 \%$ (Table 2). The microcapsule yields were not statistically different between trans-cinnamaldehyde and cinnamaldehyde type leaf oil microencapsulated with $\beta$-cyclodextrin. The polarity of different ratios of ethanol to water in the reaction solution may influence the co-precipitation during microencapsulation.

Hill et al. [16] investigated the stability constants $(\mathrm{Kc})$ of trans-cinnamaldehyde/ $\beta$-cyclodextrin inclusion complexes at three different temperatures $\left(25,35\right.$, and $\left.45^{\circ} \mathrm{C}\right)$, the $\mathrm{KCs}$ of inclusion complexes were $28.47,19.06$, and $18.41 \mathrm{~L} / \mathrm{mol}$, respectively; the thermodynamic results revealed that trans-cinnamaldehyde/ $\beta$-cyclodextrin inclusion complex formation was a typical lower energy reaction.

\subsection{Evaluation of the Thermostability of Leaf Oil Microcapsules by Dry-Heat Aging Test}

The weights of $\beta$-cyclodextrin ( $\beta$-CD), C. osmophloeum leaf oil (Cin oil), and leaf oil microcapsules $\left(\beta-\mathrm{CD} / \mathrm{Cin}\right.$ oil) were measured during a dry-heat aging test, performed at $105^{\circ} \mathrm{C}$ in a ventilated oven, as shown in Figure 3. The weight percentage of $\beta$-cyclodextrin was kept constant during the accelerated aging test; $\beta$-cyclodextrin was thermostable at $105{ }^{\circ} \mathrm{C}$. Trotta et al. reported that the decomposition temperature of $\beta$-cyclodextrin was ca. $250{ }^{\circ} \mathrm{C}$ according to the thermogravimetric analysis (TGA) [21]. The weight percentages of leaf oil were $11.7 \%$ and $0 \%$ after $30 \mathrm{~min}$ and $1 \mathrm{~h}$ of aging test, respectively (data not shown in Figure 3). Emission of C. osmophloeum leaf oil was quick in the high 
temperature external environment; high volatility of leaf oil was a problem for its utility. The weight loss of leaf oil microcapsules was $4.92 \%$ after 1 day of aging test. Comparing the weight loss between leaf oil and leaf oil microcapsules, it is clear that microencapsulation reduced the emission of leaf oil in the early stages of the dry-heat aging test. Weight percentages of leaf oil microcapsules were $88.4 \%$ and $88.1 \%$ after 4 and 8 days of the aging test. The weight percentages of leaf oil microcapsules after 4 days and 8 days were significantly lower than those before 2 days. This corresponded with the leaf oil content in microcapsules. Microencapsulation of leaf oil with $\beta$-cyclodextrin thus slowed down the volatility of the leaf oil, revealing that the thermostability of C. osmophloeum leaf oil was effectively improved by encapsulation with $\beta$-cyclodextrin.

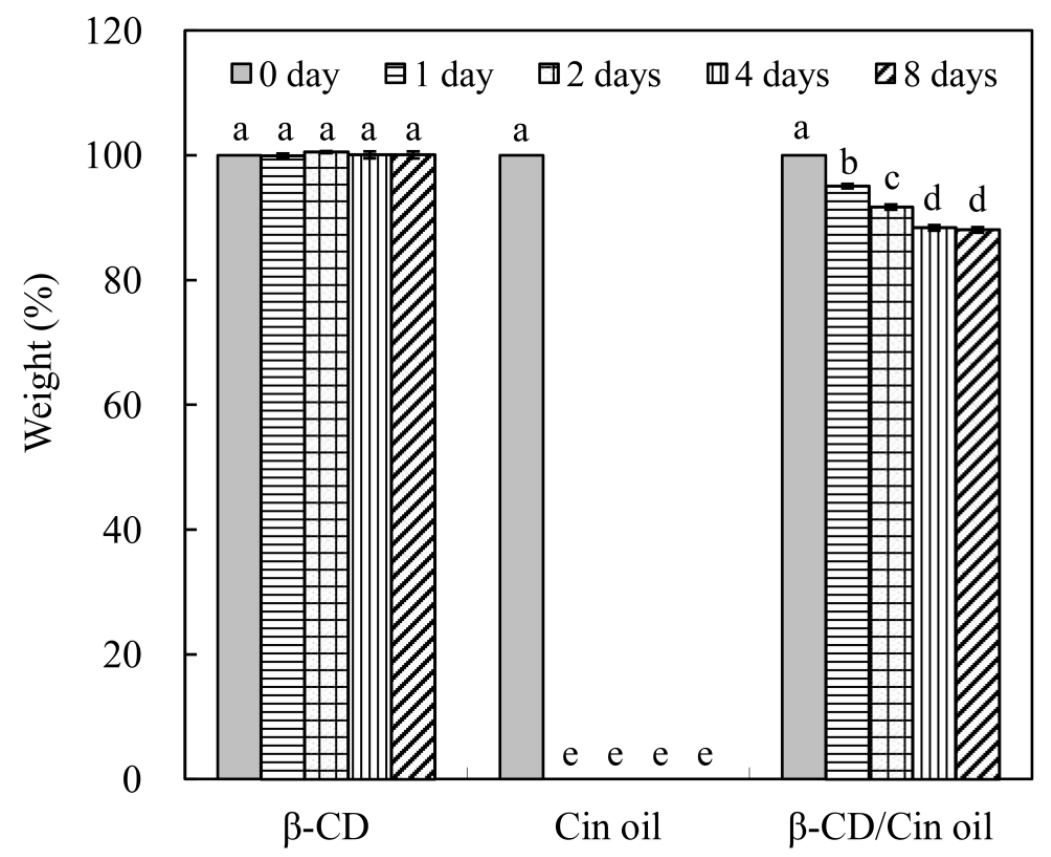

Figure 3. Changes in weight of leaf oil microcapsules during the dry-heat aging test. $\beta$-CD: $\beta$-cyclodextrin; Cin oil: C. osmophloeum leaf oil; $\beta$-CD/Cin oil: leaf oil microcapsules; Different letters (a-e) in the Figure refer to statistically significant difference at the level of $p<0.05$ according to the Scheffe's test.

Changes of the characteristic peaks occurred in the FTIR spectrum of C. osmophloeum leaf oil microcapsules ( $\beta$-CD/Cin oil) after the dry-heat aging test, as shown in Figure 4. The relative intensities of the absorption peaks at $1630 \mathrm{~cm}^{-1}$ and $1681 \mathrm{~cm}^{-1}$ decreased during the aging period. Peaks at $1630 \mathrm{~cm}^{-1}$ (for $\mathrm{C}=\mathrm{C}$ stretching vibrations) and $1681 \mathrm{~cm}^{-1}$ (for $\mathrm{C}=\mathrm{O}$ stretching vibrations) are the characteristic absorptions of the extended conjugation structure of trans-cinnamaldehyde [22], the major constituent of leaf oil. The decrease of these absorption bands with the aging period resulted from the emission of trans-cinnamaldehyde in the environment at $105^{\circ} \mathrm{C}$. The characteristic absorption bands of $\beta$-cyclodextrin are $3386 \mathrm{~cm}^{-1}$ (for $\mathrm{O}-\mathrm{H}$ stretching vibrations), $2926 \mathrm{~cm}^{-1}$ (for $-\mathrm{CH}_{2}$ asymmetrical stretching vibrations) and $1165 \mathrm{~cm}^{-1}$ (for C-O stretching vibrations) [23-25]. These characteristic peaks of $\beta$-cyclodextrin didn't show any differences in the FTIR spectrum after the dry-heat aging test; revealing that the molecules of $\beta$-cyclodextrin were thermostable during 8 days of aging. The results from the FTIR spectroscopic analysis ensured the consistency of the thermostability of $\beta$-cyclodextrin observed in Figure 3. Most constituents of the leaf oil were control released from the microcapsules during the dry-heat aging test. 


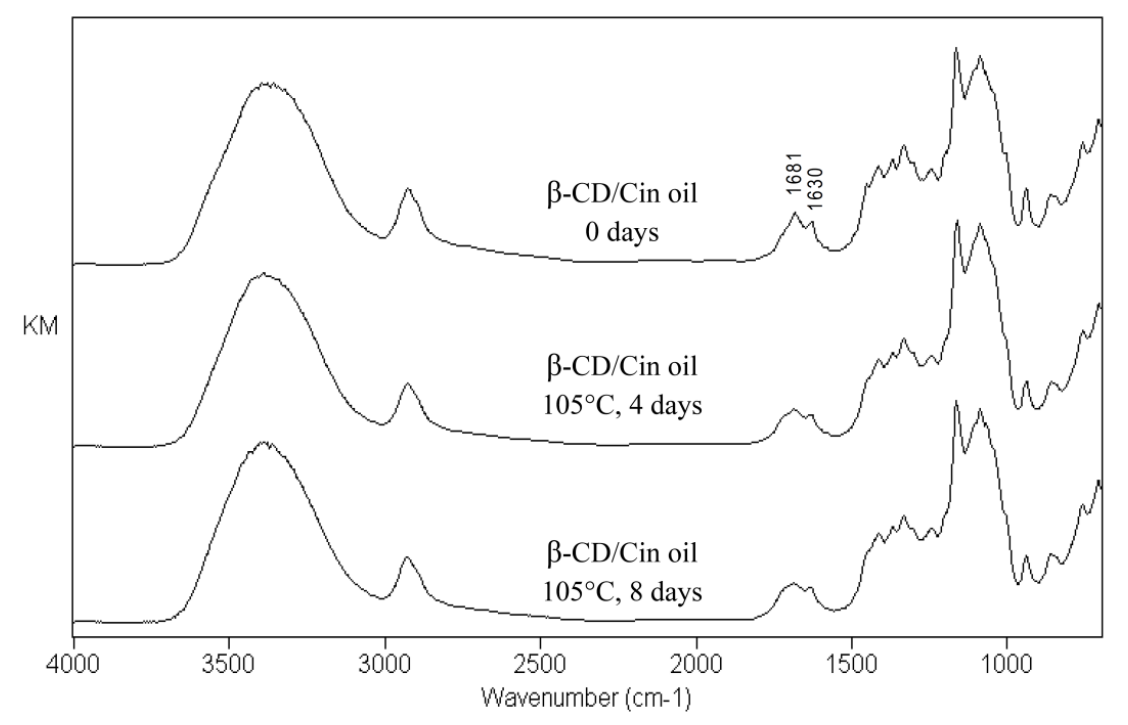

Figure 4. FTIR spectra of Cinnamomum osmophloeum leaf oil microcapsules after the dry-heat aging treatment.

\subsection{Xanthine Oxidase Inhibitory Activities of C. Osmophloeum Leaf Oil Microcapsules}

Wang et al. [1] evaluated the xanthine oxidase inhibitory activities of ethanolic extract, hot water extract, and essential oil of cinnamaldehyde-type C. osmophloeum leaf; leaf oil, which contained $75.1 \%$ of trans-cinnamaldehyde, possessed the best activity with a half maximal inhibitory concentration $\left(\mathrm{IC}_{50}\right)$ value of $16.3 \mu \mathrm{g} / \mathrm{mL}$. In this study, trans-cinnamaldehyde content in examined leaf oil was $84.1 \%$ (Table 1 ), and the $\mathrm{IC}_{50}$ value of xanthine oxidase inhibitory activity of leaf oil was $11.2 \mu \mathrm{g} / \mathrm{mL}$ (Table 3). Xanthine oxidase inhibitory activity of C. osmophloeum leaf oil increased with the content of trans-cinnamaldehyde in leaf oil.

Table 3. Xanthine oxidase inhibitory activity of leaf oil and leaf oil microcapsules.

\begin{tabular}{cc}
\hline Specimen & $\mathrm{IC}_{\mathbf{5 0}}(\mu \mathrm{g} / \mathrm{mL})$ \\
\hline$\beta-\mathrm{CD}$ & - \\
Cin oil & $11.2 \pm 0.7^{\mathrm{b} * *}$ \\
$\beta$-CD/Cin oil & $83.3 \pm 2.0^{\mathrm{a}}$ \\
Allopurinol $^{*}$ & $0.5 \pm 0.1^{\mathrm{c}}$
\end{tabular}

Cin oil: C. osmophloeum leaf oil; $\beta$-CD/Cin oil: leaf oil microcapsules; - : no effect; * Positive control; ** Different letters $(\mathrm{a}-\mathrm{c})$ in the Table refer to statistically significant difference at the level of $p<0.05$ according to Scheffe's test.

Kamimura et al. [26] reported that antioxidant activity of carvacrol, the major constituent of oregano and thyme plants oils, microencapsulated in hydroxypropyl- $\beta$-cyclodextrin was lower than that of free carvacrol. Bioactivities of essential oil/constituents after microencapsulation might vary with the different core materials and coating materials [24,27-29]. No research about the xanthine oxidase inhibitory activities of $C$. osmophloeum leaf oil microencapsulation with $\beta$-cyclodextrin has been reported in the scientific research literature. The $\mathrm{IC}_{50}$ value of xanthine oxidase inhibitory activity of leaf oil microcapsules ( $\beta-\mathrm{CD} / \mathrm{Cin}$ oil) was $83.3 \mu \mathrm{g} / \mathrm{mL}$ (Table 3). According to the leaf oil content in microcapsules $(14.9 \%)$, the calculated $\mathrm{IC}_{50}$ value of active leaf oil in microcapsules was $12.4 \mu \mathrm{g} / \mathrm{mL}$, which was comparable to leaf oil alone. Results indicated that the xanthine oxidase inhibitory activity of $C$. osmophloeum leaf oil wasn't affected by microencapsulation with $\beta$-cyclodextrin. This is the first study to report the xanthine oxidase inhibitory activity of plant essential oil microcapsules. 
Cinnamaldehyde-type C. osmophloeum leaf oil microcapsules can be used as alternative natural inhibitor for hyperuricemia and gout.

\section{Materials and Methods}

\subsection{Hydrodistillation of Leaf Oil}

C. osmophloeum leaves were collected from the Fushan Research Center of Taiwan Forestry Research Institute (Taipei, Taiwan). Leaves (100 g) were hydrodistilled in a Clevenger-type apparatus $(1 \mathrm{~L})$ for $6 \mathrm{~h}$ to obtain to obtain the leaf essential oil. The yield of leaf oil was $0.82 \pm 0.08 \%$ (mean \pm standard deviation) calculated from duplicate tests.

\subsection{GC-MS Analysis of Leaf Oil}

The composition of the leaf oil was analyzed by using a Thermo Trace GC Ultra gas chromatograph and a Polaris Q MSD mass spectrometer (Thermo Fisher Scientific, Framingham, MA, USA) equipped with a DB-5MS capillary column (Crossbond 5\% phenyl methylpolysiloxane, $30 \mathrm{~m}$ length $\times 0.25 \mathrm{~mm}$ i.d. $\times 0.25 \mu \mathrm{m}$ film thickness). The oven temperature was initially held at $60{ }^{\circ} \mathrm{C}$ for $1 \mathrm{~min}$, then increased to $220{ }^{\circ} \mathrm{C}$ at a rate of $4{ }^{\circ} \mathrm{C} / \mathrm{min}$ and held for $2 \mathrm{~min}$, and finally increased to $250{ }^{\circ} \mathrm{C}$ at a rate of $20^{\circ} \mathrm{C} / \mathrm{min}$ and held for $3 \mathrm{~min}$. Carrier gas was helium at a flow rate of $1 \mathrm{~mL} / \mathrm{min}$, and the split ratio was 1:10. Components were identified by comparing their mass spectra $(\mathrm{m} / z$ 50-650 amu) with Wiley and NIST library data, Kovats index (KI) [30], and authentic standards of constituents. Quantification of components was obtained by integrating the peak area of the chromatogram by GC coupled to a flame ionization detector (FID).

\subsection{Microencapsulation}

Microencapsulation of leaf oil in $\beta$-cyclodextrin was carried out by a published co-precipitation method with minor revisions $[20,23,31]$. Based on the previous tests, higher yields were obtained by the co-precipitation method than with other microencapsulation methods. $\beta$-Cyclodextrin $\left(\mathrm{C}_{42} \mathrm{H}_{70} \mathrm{O}_{35}, 5 \mathrm{~g}\right)$ was dissolved in ethanol/water solution $(300 \mathrm{~mL})$ at $50{ }^{\circ} \mathrm{C}$ for $5 \mathrm{~min}$, then the solution was cooled down to $25{ }^{\circ} \mathrm{C}$. Next leaf oil $(0.88 \mathrm{~g})$ was dissolved in ethanol $(10 \mathrm{~mL})$ and added to the $\beta$-cyclodextrin solution with stirring at $600 \mathrm{rpm}$ for $1 \mathrm{~h}$. The solution was refrigerated for $12 \mathrm{~h}$ at $4{ }^{\circ} \mathrm{C}$; the precipitated microcapsules (complex crystals) were vacuum-filtered and washed with $50 \mathrm{~mL}$ of distilled water. Microcapsule powders were dried at $50{ }^{\circ} \mathrm{C}$ in an oven for $24 \mathrm{~h}$ until the powder weight remained constant. The yield of microcapsules was calculated using Equation (1). The leaf oil content in microcapsules was determined by the liquid-liquid partition method; the leaf oil was extracted by the ethyl acetate and isolated from the microcapsules.

$$
\text { Yield }(\%)=\text { microcapsules }(\mathrm{g}) /[\beta \text {-cyclodextrin }(\mathrm{g})+\text { leaf oil }(\mathrm{g})] \times 100
$$

The leaf oil content in microcapsules was determined by the liquid-liquid partition method; the leaf oil was extracted by the ethyl acetate and isolated from the microcapsules.

\subsection{FTIR Analysis}

Fourier transform infrared (FTIR) spectra of leaf oil microencapsulated with $\beta$-cyclodextrin were obtained using a FTS-40 spectrometer (Bio-Rad, Hercules, CA, USA) incorporating a Spectra Tech diffuse reflectance accessory unit. The spectral resolution is $4 \mathrm{~cm}^{-1}$, and the scanning range is 4000 to $400 \mathrm{~cm}^{-1}[24,32]$.

\subsection{Dry-Heat Aging Test}

A dry-heat treatment was used to evaluate the thermostability of specimens. Leaf oil microcapsules were subjected to accelerated aged using the standard dry-heat aging test (ISO 5630-1; 
CNS 12887-1) at $105^{\circ} \mathrm{C}$ in a ventilated oven. Weights of specimens were measured during the dry-heat aging test for 1,2,4, and 8 days. After the aging test, chemical compositions of the leaf oil microcapsules were examined by FTIR analysis.

\subsection{Xanthine Oxidase Inhibitory Assay}

Xanthine is specifically oxidized by xanthine oxidase to form uric acid. The xanthine oxidase inhibitory activity was evaluated the ability of specimens, including $\beta$-cyclodextrin, leaf oil, and leaf oil microcapsules, to inhibit the formation of uric acid. The reaction mixture contained $117 \mu \mathrm{L}$ of potassium phosphate buffer (50 mM, pH 7.8), $3 \mu \mathrm{L}$ of sample (dissolved in DMSO) and $60 \mu \mathrm{L}$ of xanthine oxidase solution $(25 \mathrm{mU} / \mathrm{mL})$. The reaction was initiated by adding $100 \mu \mathrm{L}$ of $0.15 \mathrm{mM}$ xanthine solution, incubated at $37{ }^{\circ} \mathrm{C}$ for $30 \mathrm{~min}$, and stopped by adding $20 \mu \mathrm{L}$ of $1 \mathrm{~N} \mathrm{HCl}$. The absorbance of uric acid was measured at $290 \mathrm{~nm}$ by an ELISA reader [33]. Allopurinol, a gout and hyperuricemia medicine, was used as a positive control. $\mathrm{IC}_{50}$ (half maximal inhibitory concentration) values are the concentrations of specimens required for the $50 \%$ inhibition.

\subsection{Statistical Analysis}

The results were presented as mean values and standard deviations. The data were grouped by the Scheffe test of the SAS software (version 9.2) at a level of significance of $p<0.05$. The Scheffe test is a completely post-hoc multiple comparison analysis with stringent error control.

\section{Conclusions}

Constituents of C. osmophloeum leaf oil were identified by GC-MS and GC-FID. trans-Cinnamaldehyde $(84.13 \%)$, benzaldehyde $(7.16 \%), 3$-phenylpropionaldehyde (3.62\%), and $\alpha$-pinene $(1.09 \%)$ were the main constituents of the selected leaf oil. The optimal reaction conditions for microencapsulation were found at a trans-cinnamaldehyde to $\beta$-cyclodextrin ratio of 15:85 and ethanol to water ratios ranging from 1:3 to 1:5. The yield of leaf oil microcapsules was $86.3 \%$. The characteristic absorption bands of trans-cinnamaldehyde were confirmed in the FTIR spectra of leaf oil microcapsules. The thermostability of leaf oil microcapsules were evaluated by the dry-heat aging test, and $\beta$-cyclodextrin was thermostable at $105{ }^{\circ} \mathrm{C}$ and had efficacy to retard the emission of C. osmophloeum leaf oil. The xanthine oxidase inhibitory activity of cinnamaldehyde-type C. osmophloeum leaf oil was not affected after microencapsulation with $\beta$-cyclodextrin and the $\mathrm{IC}_{50}$ value of leaf oil microcapsules in the xanthine oxidase inhibitory assay was in good agreement with the content of leaf oil in the microcapsules. These results revealed that cinnamaldehyde-type C. osmophloeum leaf oil microencapsulated with $\beta$-cyclodextrin possessed superior thermostability and xanthine oxidase inhibitory activity. Cinnamaldehyde-type C. osmophloeum leaf oil microencapsules have great potential to be used as a natural xanthine oxidase inhibitor for dietary supplements and treatment of hyperuricemia and gout.

Author Contributions: Conceptualization, S.-T.C. and H.-T.C.; Methodology, H.-T.C. and F.-L.H.; Software, C.-Y.H. and C.-Y.L.; Validation, T.-F.Y. and F.-L.H.; Formal Analysis and Investigation, C.-Y.H., C.-Y.L. and H.-T.C.; Writing-Original Draft Preparation, H.-T.C.; Writing-Review \& Editing, T.-F.Y. and H.-T.C.

Funding: This research was funded by Forestry Bureau [100-00-5-10], Council of Agriculture, Executive Yuan, Taipei, Taiwan.

Acknowledgments: The authors would like to express our greatest thanks appreciation to Taiwan Forestry Research Institute for providing C. osmophloeum materials and the Forestry Bureau, Taiwan, for the financial support.

Conflicts of Interest: The authors declare no conflict of interest. 


\section{References}

1. Wang, S.Y.; Yang, C.W.; Liao, J.W.; Zhen, W.W.; Chu, F.H.; Chang, S.T. Essential oil from leaves of Cinnamomum. osmophloeum acts as a xanthine oxidase inhibitor and reduces the serum uric acid levels in oxonate-induced mice. Phytomedicine 2008, 15, 940-945. [CrossRef] [PubMed]

2. Melgarejo-Flores, B.G.; Ortega-Ramirez, L.A.; Silva-Espinoza, B.A.; Gonzalez-Aguilar, G.A.; Miranda, M.R.A.; Ayala-Zavala, J.F. Antifungal protection and antioxidant enhancement of table grapes treated with emulsions, vapors, and coatings of cinnamon leaf oil. Postharvest Biol. Technol. 2013, 86, 321-328. [CrossRef]

3. Wu, C.L.; Chang, H.T.; Hsui, Y.R.; Hsu, Y.W.; Liu, J.Y.; Wang, S.Y.; Chang, S.T. Antioxidant-enriched leaf water extracts of Cinnamomum. osmophloeum from eleven provenances and their bioactive flavonoid glycosides. BioResources 2013, 5, 571-580. [CrossRef]

4. Cheng, B.H.; Sheen, L.Y.; Chang, S.T. Evaluation of anxiolytic potency of essential oil and S-(+)-linalool from Cinnamomum. osmophloeum ct. linalool leaves in mice. J. Tradit. Complement. Med. 2015, 5, 27-34. [CrossRef] [PubMed]

5. Davaatseren, M.; Jo, Y.J.; Hong, G.P.; Hur, H.J.; Park, S.; Choi, M.J. Studies on the Anti-oxidative function of trans-cinnamaldehyde-included $\beta$-cyclodextrin complex. Molecules 2017, 21, 1644. [CrossRef] [PubMed]

6. Kaiser, C.S.; Rompp, H.; Schmidt, P.C. Supercritical carbon dioxide extraction of chamomile flowers: extraction efficiency, stability, and in-line inclusion of chamomile-carbon dioxide extract in $\beta$-cyclodextrin. Phytochem. Anal. 2004, 15, 249-256. [CrossRef] [PubMed]

7. Wang, J.; Cao, Y.; Sun, B.; Wang, C. Physicochemical and release characterisation of garlic oil- $\beta$-cyclodextrin inclusion complexes. Food Chem. 2011, 127, 1680-1685. [CrossRef]

8. Pires, M.A.S.; Santos, R.A.S.; Sinisterra, R.D. Pharmaceutical composition of hydrochlorothiazide: $\beta$-cyclodextrin: preparation by three different methods, physico-chemical characterization and in vivo diuretic activity evaluation. Molecules 2011, 16, 4482-4499. [CrossRef] [PubMed]

9. Moya-Ortega, M.D.; Alvarez-Lorenzo, C.; Concheiro, A.; Loftsson, T. Cyclodextrin-based nanogels for pharmaceutical and biomedical applications. Int. J. Pharm. 2012, 428, 152-163. [CrossRef] [PubMed]

10. Szente, L.; Szeman, J.; Sohajda, T. Analytical characterization of cyclodextrins: History, official methods and recommended new techniques. J. Pharm. Biomed. Anal. 2016, 130, 347-365. [CrossRef] [PubMed]

11. Waleczek, K.J.; Marques, H.M.C.; Hempel, B.; Schmidt, P.C. Phase solubility studies of pure (2)- $\alpha$-bisabolol and camomile essential oil with $\beta$-cyclodextrin. Eur. J. Pharm. Biopharm. 2003, 55, 247-251. [CrossRef]

12. Iacovino, R.; Caso, J.V.; Rapuano, F.; Russo, A.; Isidori, M.; Lavorgna, M.; Gaetano Malgieri, G.; Isernia, $\mathrm{C}$. Physicochemical characterization and cytotoxic activity evaluation of hydroxymethylferrocene: $\beta$-Cyclodextrin inclusion complex. Molecules 2012, 17, 6056-6070. [CrossRef] [PubMed]

13. Ciobanu, A.; Mallard, I.; Landy, D.; Brabie, G.; Nistor, D.; Fourmentin, S. Retention of aroma compounds from Mentha piperita essential oil by cyclodextrins and crosslinked cyclodextrin polymers. Food Chem. 2013, 138, 291-297. [CrossRef] [PubMed]

14. Donato, C.D.; Lavorgna, M.; Fattorusso, R.; Isernia, C.; Isidori, M.; Malgieri, G.; Piscitelli, C.; Russo, C.; Russo, L.; Iacovino, R. Alpha- and beta-cyclodextrin inclusion complexes with 5-fluorouracil: characterization and cytotoxic activity evaluation. Molecules 2016, 22, 1868. [CrossRef] [PubMed]

15. Szejtli, J. Introduction and general overview of cyclodextrin chemistry. Chem. Rev. 1998, 98, 1743-1753. [CrossRef] [PubMed]

16. Hill, L.E.; Gomes, C.; Taylor, T.M. Characterization of beta-cyclodextrin inclusion complexes containing essential oils (trans-cinnamaldehyde, eugenol, cinnamon bark, and clove bud extracts) for antimicrobial delivery applications. LWT-Food Sci. Technol. 2013, 51, 86-93. [CrossRef]

17. Spada, G.; Gavini, E.; Cossu, M.; Rassu, G.; Carta, A.; Giunchedi, P. Evaluation of the effect of hydroxypropyl $\beta$-cyclodextrin on topical administration of milk thistle extract. Carbohydr. Polym. 2013, 92, 40-47. [CrossRef] [PubMed]

18. Quintans, J.S.S.; Menezes, P.P.; Santos, M.R.V.; Bonjardim, L.R.; Almeida, J.R.G.S.; Gelain, D.P.; Araujo, A.A.S.; Quintans-Junior, L.J. Improvement of $p$-cymene antinociceptive and anti-inflammatory effects by inclusion in $\beta$-cyclodextrin. Phytomedicine 2013, 20, 436-440. [CrossRef] [PubMed]

19. Jiang, S.; Li, J.N.; Jiang, Z.T. Inclusion reactions of $\beta$-cyclodextrin and its derivatives with cinnamaldehyde in Cinnamomum. loureirii essential oil. Eur. Food Res. Technol. 2010, 230, 543-550. [CrossRef] 
20. Ayala-Zavala, J.F.; Soto-Valdez, H.; Gonzalez-Leon, A.; Alvarez-Parrilla, E.; Martin-Belloso, O.; Gonzalez-Aguilar, G.A. Microencapsulation of cinnamon leaf (Cinnamomum. zeylanicum) and garlic (Allium sativum) oils in $\beta$-cyclodextrin. J. Incl. Phenom. Macrocycl. Chem. 2008, 60, 359-368. [CrossRef]

21. Trotta, F.; Zanetti, M.; Camino, G. Thermal degradation of cyclodextrins. Polym. Degrad. Stab. 2000, 69, 373-379. [CrossRef]

22. Muller, J.; Gonzalez-Martinez, C.; Chiralt, A. Poly(lactic) acid (PLA) and starch bilayer films, containing cinnamaldehyde, obtained by compression moulding. Eur. Polym. J. 2017, 95, 56-70. [CrossRef]

23. Liu, H.; Yang, G.; Tang, Y.; Cao, D.; Qi, T.; Qi, Y.; Fan, G. Physicochemical characterization and pharmacokinetics evaluation of $\beta$-caryophyllene/ $\beta$-cyclodextrin inclusion complex. Int. J. Pharm. 2013, 450, 304-310. [CrossRef] [PubMed]

24. Ferreira, F.R.; Valentim, I.B.; Ramones, E.L.C.; Trevisan, M.T.S.; Olea-Azar, C.; Perez-Cruz, F.; Abreu, F.C.; Goulart, M.O.F. Antioxidant activity of the mangiferin inclusion complex with $\beta$-cyclodextrin. LWT-Food Sci. Technol. 2013, 51, 129-134. [CrossRef]

25. Wang, X.; Luo, Z.; Xiao, Z. Preparation, characterization, and thermal stability of $\beta$-cyclodextrin/soybean lecithin inclusion complex. Carbohydr. Polym. 2014, 101, 1027-1032. [CrossRef] [PubMed]

26. Kamimura, J.A.; Santos, E.H.; Hill, L.E.; Gomes, C.L. Antimicrobial and antioxidant activities of carvacrol microencapsulated in hydroxypropyl-beta-cyclodextrin. LWT-Food Sci. Technol. 2014, 57, 701-709. [CrossRef]

27. Guimaraes, A.G.; Oliveira, M.A.; Alves, R.S.; Menezes, P.P.; Serafini, M.R.; Araujo, A.A.S.; Bezerra, D.P.; Quintans, L.J. Encapsulation of carvacrol, a monoterpene present in the essential oil of oregano, with $\beta$-cyclodextrin, improves the pharmacological response on cancer pain experimental protocols. Chem. Biol. Interact. 2015, 227, 69-76. [CrossRef] [PubMed]

28. Nascimento, S.S.; Araujo, A.A.S.; Brito, R.G.; Serafini, M.R.; Menezes, P.P.; DeSantana, J.M.; Lucca, W.; Alves, P.B.; Blank, A.F.; Oliveira, R.C.M.; et al. Cyclodextrin-complexed Ocimum. basilicum leaves essential oil increases Fos protein expression in the central nervous system and produce an antihyperalgesic effect in animal models for fibromyalgia. Int. J. Mol. Sci. 2015, 16, 547-563. [CrossRef] [PubMed]

29. Bomfim, L.M.; Menezes, L.R.; Rodrigues, A.C.; Dias, R.B.; Rocha, C.A.; Soares, M.B.; Neto, A.F.; Nascimento, M.P.; Campos, A.F.; Silva, L.C.; et al. Antitumour activity of the microencapsulation of Annona vepretorum essential oil. Basic Clin. Pharmacol. Toxicol. 2016, 118, 208-213. [CrossRef] [PubMed]

30. Adams, R.P. Identification of Essential Oil Components by Gas. Chromatography/Mass Spectrometry; Allured Publishing Corporation: Carol Stream, IL, USA, 2007; pp. 6-398. ISBN 978-1932633214.

31. Abarca, R.L.; Rodriguez, F.J.; Guarda, A.; Galotto, M.J.; Bruna, J.E. Characterization of beta-cyclodextrin inclusion complexes containing an essential oil component. Food Chem. 2016, 196, 968-975. [CrossRef] [PubMed]

32. Chang, H.T.; Su, Y.C.; Chang, S.T. Studies on photostability of butyrylated, milled wood lignin using spectroscopic analyses. Polym. Degrad. Stab. 2006, 91, 816-822. [CrossRef]

33. Ahmad, N.S.; Farman, M.; Najmi, M.H.; Mian, K.B.; Hasan, A. Pharmacological basis for use of Pistacia. integerrima leaves in hyperuricemia and gout. J. Ethnopharmacol. 2008, 117, 478-482. [CrossRef] [PubMed]

Sample Availability: Samples of the microcapsules are available from the authors.

(C) 2018 by the authors. Licensee MDPI, Basel, Switzerland. This article is an open access article distributed under the terms and conditions of the Creative Commons Attribution (CC BY) license (http:// creativecommons.org/licenses/by/4.0/). 